\title{
EVALUASI KINERJA KEGIATAN PERAWATAN MESIN INJECTION MOLD MENGGUNAKAN METODE TOTAL PRODUCTIVE MAINTENANCE (TPM) PADA PT ICHIKOH INDONESIA
}

\author{
M. Tirtana Siregar ${ }^{1}$, Abdullah ${ }^{2}$ \\ Manajemen Logistik Industri Elektronika \\ Politeknik APP Jakarta, Indonesia \\ e-mail : ${ }^{1}$ tirtana.mts@gmail.com, ${ }^{2}$ abdullah@gmail.com
}

Diterima: 12 Nopember 2017. Disetujui : 26 Nopember 2017. Dipublikasikan : 4 Desember 2017

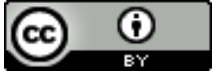

(C)2017 -TESJ Fakultas Teknik Universitas Maarif Hasyim Latif. Ini adalah artikel dengan akses terbuka di bawah lisensi CC BY 4.0 (https://creativecommons.org/licenses/by/4.0/)

\section{ABSTRAK}

Penelitian ini bertujuan untuk memberikan gambaran deskriptif mengenai perawatan mesin atau maintenance, meliputi Total Productive Maintenance, Overall Equipment Effectiveness, Overall Human Ineffectiveness dan Six Big Losses pada PT Ichikoh Indonesia. Permasalahan yang terjadi diperusahaan yaitu banyaknya jumlah part defect dikarenakan mesin sering breakdown. Pengumpulan data dilakukan dengan observasi dan wawancara terstruktur dengan Manager Departement Molding Upstream 1 dan Departement Maintenance. Data tersebut dianalisis menggunakan metode kuantitatif dan evaluatif dari periode bulan April 2016 sampai Maret 2017. Dari hasil analisis ini PT Ichikoh Indonesia memiliki nilai efektifitas mesin yang masih dibawah standar JIPM (Japan Institude of Plant Maintenance) yaitu dengan nilai tertinggi pada bulan Februari 74\%, sedangkan standar JIPM (Japan Institude of Plant Maintenance) adalah minimal sebesar 85\% yang dihitung menggunakan metode Overall Equipment Effectiveness. Sedangkan untuk pengukuran tingkat ketidakefektifan kerja operator yang dianalisis menggunakan metode Overall Human Ineffectiveness mendapatkan nilai yang masih besar pada bulan Mei 2016 yaitu sebesar 17\%. Faktor yang menyebabkan rendahnya nilai efektifitas mesin dan tingkat ketidakefektifan kinerja operator adalah faktor Idling and Minor Stoppagges dengan nilai losses sebesar 54\% yang sudah dianalisis menggunakan diagram pareto. Sesuai dengan diagram sebab-akibat (fishbone) didapat faktor-faktor yang menyebabkan terjadinya Idling and Minor Stoppagges yang menjadi prioritas utama adalah a) faktor manusia yaitu masih kurang disiplin, sering terjadi kesalahan dalam perbaikan mesin, b) faktor material yaitu kesalahan spesifikasi material dan rendahnya perawatan bahan baku, c) faktor mesin yaitu mesin sering breakdown, kesalahan setup, d) faktor metode yaitu penjadwalan pengganti komponen yang belum efektif dan autonomous maintenance kurang berjalan dengan baik, e) faktor lingkungan yaitu kebersihan mesin kurang.

Kata Kunci : Overall Equipment Effectiveness, Overall Human Ineffectiveness, Perawatan mesin, Six Big Losses, Total Productive Maintenance, Diagram Pareto dan Diagram Sebab-Akibat (Fishbone).

\section{PENDAHULUAN}

Perkembangan Teknologi di bidang manufaktur belakangan ini semakin meningkat seiring dengan tuntutan konsumen yang terus menginginkan agar pabrik dapat memenuhi kebutuhan konsumen secara cepat. Berdasarkan data Badan Pusat Statistik (BPS), Pertumbuhan produksi industri manufaktur besar dan sedang tahun 2016 naik 4,00\% dibanding tahun 2015. Didukung oleh data dari Indonesia Investments untuk penjualan mobil di Indonesia.

Gambar 1 menjelaskan tentang perbandingan penjualan mobil di Indonesia dari tahun 2009 sampai dengan 2016. Pada tahun 2009 penjualan mobil di Indonesia berjumlah 486.061 unit, bertambah menjadi 764.710 unit pada tahun
2010, bertambah menjadi 894.164 unit pada tahun 2011, bertambah menjadi 1.116 .230 unit ditahun 2012, bertambah menjadi 1.229 .916 unit ditahun 2013 dan menurun menjadi 1.208 .019 unit ditahun 2014, menurun menjadi 1.013.291 unit pada tahun 2015 serta bertambah naik ditahun 2016 menjadi 1.061.735 unit. Tahun 2016 penjualan mobil di Indonesia naik 4\% dari pada tahun 2015.

PT. Ichikoh Indonesia adalah perusahaan yang berdiri dari Maret 1997 dengan luas wilayah $29,968 \mathrm{~m}^{2}$ dan luas gedungnya $17.600 \mathrm{~m}^{2}$ ini bergerak dalam pengembangan dan pembuatan bagianbagian listrik untuk mobil (lampu), cermin dan komponen otomotif lainnya seperti sparepart mobil dan motor. Yang beralamatkan di Jalan Irian Blok LL-1 Kawasan MM2100 Industrial Town, Cikarang Barat, Bekasi, Jawa Barat. Dan mempunyai 
cabang dibeberapa negara yaitu Indonesia, Vietnam, Thailand dan Malaysia. Dalam proses produksinya, departemen Molding menggunakan mesin yang berbeda beda, departemen Molding mempunyai 22 mesin yang masing masing mesin mempunyai kurang lebih 3 cetakan yang berbeda dan produk yang dihasilkannya juga berbeda. Proses produksi dilakukan secara terus menerus selama 24 Jam dengan menggunakan 3 Shift.

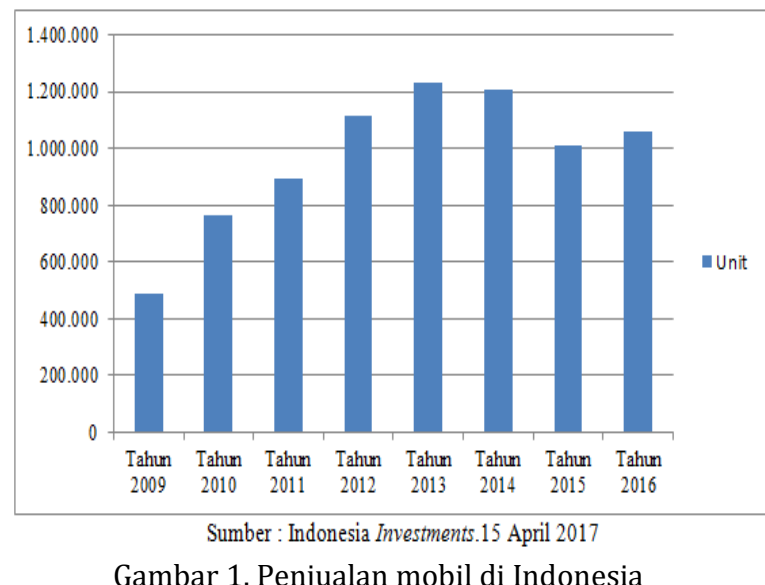

Sebagai perusahaan yang bergerak dibidang manufakturing otomotif, PT. Ichikoh Indonesia berusaha untuk menghasilkan produk yang optimal sesuai dengan rencana produksi yang telah ditetapkan yaitu nol cacat (Zero Defect). Sesuai data wawancara yang penulis lakukan oleh pihak Manager PT. Ichikoh Indonesia bahwa beberapa bulan terakhir ini PT. Ichikoh Indonesia menghasilkan besarnya persentase produk cacat yang berakibat tidak tercapainya target nol cacat (Zero Defect) yang sebelumnya telah direncanakan, dikarenakan mold yang berada dalam mesin Injection tersebut sering mengalami kemacetan, selang airnya (Coupler) bocor, saluran air mold mampet, atau mold terdapat goresan (Scratch) dan lain lain yang secara langsung mengakibatkan produktifitas waktu efektif proses produksi terganggu.

Kejadian kerusakan pada mold tersebut akan berakibat kerugian yang cukup besar bagi perusahaan. Untuk mengatasi masalah tersebut diperlukan langkah-langkah yang tepat dalam pemeliharaan mesin atau peralatan, salah satunya dengan melakukan penerapan Total Productive Maintenance. Evaluasi penerapan Total Productive Maintenance dilakukan dengan menggunakan nilai Overall Equipment Effectiveness sebagai indikator serta mencari penyebab ketidakefektifan dari mesin tersebut dengan melakukan perhitungan six big losses untuk mengetahui faktor yang berpengaruh dari keenam faktor six big losses yang ada serta melakukan perhitungan nilai Overall Human Ineffectiveness untuk mengetahui tingkat ketidakefektifan operator pada saat melakukan pekerjaannya.
Keterkaitan perawatan mesin dengan Overall $\mathrm{Hu}$ man Ineffectiveness adalah kedua hal tersebut sama-sama berfungsi untuk meningkatkan kualitas perusahaan dalam artian perawatan mesin untuk meningkatkan kualitas mesinnya sedangkan Overall Human Ineffectiveness untuk meningkatkan kinerja karyawannya dengan cara mengurangi faktor-faktor dalam Overall Human Ineffectiveness dikarenakan kegiatan perawatan mesin di PT Ichikoh Indonesia dilakukan terlebih dahulu oleh operator produksi, jika operator produksi tidak mampu menangani maka perbaikan atau perawatan dilakukan oleh leader, supervisor, divisi maintenance dan divisi engineering. Dengan melakukan perhitungan Overall Equipment Effectiveness dan Overall Human Ineffectiveness, perusahaan akan mengetahui dimana posisi mereka dan dimana titik kelemahan serta bagaimana cara melakukan perbaikan. Perawatan mesin (maintenance) di PT. Ichikoh Indonesia dilakukan dengan Annual Schedule Maintenance yang berguna untuk catatan penjadwalan perawatan mesin yang harus dilakukan. Perawatan mesin mold diterapkan sesuai target shots mesin mold itu sendiri, mesin mold 350 TonD dilakukan perawatan mesin jika target shots sudah mencapai 6.000 kali shots. Kegiatan perawatan mesin mold dengan cara mengisi lembar Mold Analisys Check Sheet yang sudah tersedia.

\section{METODE PENELITIAN}

PT. Ichikoh Indonesia merupakan pabrik yang bergerak pada bidang manufakturing khususnya pembuatan bagian-bagian listrik untuk mobil (lampu), cermin dan komponen otomotif lainnya seperti sparepart mobil dan motor. Proses produksinya berjalan secara continue atau terusmenerus selama 24 jam dalam satu hari kerja terbagi menjadi 3 shift yaitu shift 1 dimulai dari pukul 07.00 WIB - 15.00 WIB, shift 2 dimulai dari pukul 15.00 WIB - 23.00 WIB dan shift 3 dimulai dari pukul 23.00 WIB - 07.00 WIB.

Berdasarkan Identification Problem yang dihasilkan dari wawancara dengan pembimbing lapangan, maka mesin yang menjadi objek penelitian adalah Injection Mold Machine Toshiba Yushin 350 Ton-D yang menghasilkan produk 6D2 $1^{\text {st }}$ Lens. Adapun alasan mesin Injection Mold Machine Toshiba Yushin 350 Ton-D dijadikan objek penelitian adalah:

1. perawatan pada mesin Injection mold $350 \mathrm{~T}-\mathrm{D}$ ini lebih sering dibandingkan mesin-mesin lainnya.

2. tolok ukur dalam perawatan yaitu jika shoot mold sudah mencapai 6.000 kali atau sudah dalam jangka waktu seminggu. 


\section{Data Jam Kerja (Available Time) dan Delay Me-} $\sin$

Data jam kerja (available time) adalah jam kerja yang tersedia diperusahaan untuk melakukan proses produksi. Perhitungan data jam kerja adalah dengan cara nilai X (jumlah hari dalam sebulan) dikurangi dengan Y (Jumlah hari libur dalam sebulan) lalu dikalikan dengan $\mathrm{Z}$ (waktu dalam satu hari).

Sedangkan perhitungan delay mesin hanya penambahan dari seluruh faktor-faktor yang menyebabkan terjadinya delay pada mesin. Dari hasil pengamatan pada mesin Injection Mold Toshiba Yushine 350 Ton-D di divisi molding, faktor-faktor yang menyebabkan delay pada mesin Injection Mold Toshiba Yushine 350 Ton-D sebagai berikut:

1. Planned Stop By MPS, yaitu pemberhentian produksi dikarenakan produk dimesin tersebut tidak dijadwalkan oleh pihak Production Planning.

2. Organization Malfuncion, yaitu hilangnya waktu efektif bekerja dikarenakan tidak ada operator mesin atau banyaknya waiting time yang ada pada saat proses produksi seperti, menunggu box datang, menunggu crane, overstock dan sebagainya.
3. Trouble Process, yaitu waktu dimana terjadi kerusakan pada saat proses produksi yang dapat menghambat kinerja mesin. Contoh : material gosong, material mampet dan lain sebagainya.

4. Trouble Dies, yaitu kerusakan atau gangguan terhadap mold yang menyebabkan proses produksi berhenti untuk sementara waktu. Contoh : saluran air mold mampet, mold terdapat goresan, mold seret, dan lain sebagainya.

5. Trouble Machine and Equipment, yaitu kerusakan atau gangguan yang terjadi selama proses produksi terhadap mesin itu sendiri yang menyebabkan berhentinya proses produksi untuk sementara waktu. Contoh : mesin nge-trip (mengadat), Nozzle mampet, Dryer temperaturnya labil, mesin robot error dan lain sebagainya.

6. Changeover, yaitu waktu dimana dibutuhkan untuk pemeliharaan mesin guna mencegah terjadinya kerusakan pada mold atau mesin. Contoh : pencucian mold (Dandori), ganti material, ganti insert core dan lain sebagainya.

7. Preparation After Stop, yaitu waktu dimana persiapan mesin sebelum dioperasikan. Contoh : tunggu temperatur mold atau barrel,

Tabel 1. Data produksi 6D2 $1^{\text {st }}$ Lens

bulan April 2016 - Maret 2017
\begin{tabular}{|c|c|}
\hline Bulan & $\begin{array}{c}\text { Produksi } 6 \mathrm{D} 2 \\
1 \text { st Lens }\end{array}$ \\
\hline Apr-2016 & 57.332 \\
\hline May-2016 & 61.461 \\
\hline Jun-2016 & 61.427 \\
\hline Jul-2016 & 33.389 \\
\hline Aug-2016 & 18.409 \\
\hline Sep-2016 & 40.366 \\
\hline Oct-2016 & 22.575 \\
\hline Nov-2016 & 34.130 \\
\hline Dec-2016 & 41.400 \\
\hline Jan-2017 & 2.393 \\
\hline Feb-2017 & 56.800 \\
\hline Mar-2017 & 59.783 \\
\hline TOTAL & 489.465 \\
\hline
\end{tabular}

Tabel 2. Data produksi produk OK dan produk Defect pada bulan April 2016 - Maret 2017

\begin{tabular}{c|c|c|c|c|c}
\hline \multirow{2}{*}{ Bulan } & \multirow{2}{*}{$\begin{array}{c}\text { Produksi 6D2 } \\
\text { 1" }\end{array}$} & \multirow{2}{*}{$\begin{array}{c}\text { Jumlah } \\
\text { produk OK }\end{array}$} & \multicolumn{3}{|c}{ Produk Defect } \\
\cline { 4 - 6 } & & & Rework & Scrap & Total \\
\hline Apr-2016 & 57.332 & 56.218 & 780 & 334 & 1.114 \\
\hline May-2016 & 61.461 & 60.209 & 877 & 375 & 1.252 \\
\hline Jun-2016 & 61.427 & 60.199 & 860 & 368 & 1.228 \\
\hline Jul-2016 & 33.389 & 32.517 & 611 & 261 & 872 \\
\hline Aug-2016 & 18.409 & 18.021 & 272 & 116 & 388 \\
\hline Sep-2016 & 40.366 & 39.669 & 488 & 209 & 697 \\
\hline Oct-2016 & 22.575 & 20.407 & 1.518 & 650 & 2.168 \\
\hline Nov-2016 & 34.130 & 27.057 & 4.952 & 2.121 & 7.073 \\
\hline Dec-2016 & 41.400 & 40.295 & 774 & 331 & 1.105 \\
\hline Jan-2017 & 2.393 & 2.347 & 33 & 13 & 46 \\
\hline Feb-2017 & 56.800 & 55.695 & 884 & 221 & 1.105 \\
\hline Mar-2017 & 59.783 & 58.092 & 1.184 & 507 & 1.691 \\
\hline TOTAL & 489.465 & 470.726 & 13.233 & 5.506 & \\
\hline
\end{tabular}


membersihkan area dan tools setelah breakdown, dan lain sebagainya.

\section{Perhitungan Overall Equipment Effectiveness (OEE)}

Untuk mengetahui besarnya efektivitas mesin atau peralatan secara keseluruhan pada PT. Ichikoh Indonesia, maka terlebih dahulu harus memperoleh nilai-nilai availability ratio, performance efficiency, rate of quality product dihitung dengan menggunakan rumus (1).

$$
O E E(\%)=A R(\%) \times P E(\%) \times Q R(\%)
$$

Keterangan :

AR: Availability Ratio

$P E$ : Performance Efficiency

QR: Quality Rate

\section{Perhitungan Six Big Losses \\ Downtime Losses}

Di dalam perhitungan OEE, yang termasuk dalam downtime losses adalah equipment failure dan setup and adjusment

\section{HASIL DAN PEMBAHASAN}

Data produksi di PT. Ichikoh Indonesia disajikan di Tabel 1 dan jumlah produk OK dengan produk Defect perbulannya pada Tabel 2. Data ini merupakan rekapitulasi dari laporan produksi PT. Ichikoh Indonesia.

\section{Data Jam Kerja (Available Time) dan Delay Me- $\sin$ \\ Data jam kerja (available time) adalah jam} kerja yang tersedia diperusahaan untuk melakukan proses produksi. Perhitungan data jam kerja adalah dengan cara nilai X (jumlah hari dalam sebulan) dikurangi dengan Y Uumlah hari libur dalam sebulan) lalu dikalikan dengan $\mathrm{Z}$ (waktu dalam satu hari)

Sedangkan perhitungan delay mesin hanya penambahan dari seluruh faktor-faktor yang menyebabkan terjadinya delay pada mesin. Dari hasil

Tabel 3. Perhitungan data jam kerja (Available time)

\begin{tabular}{|c|c|c|c|}
\hline Bulan & $\begin{array}{c}\text { Jumlah hari } \\
\text { dalam sebulan } \\
\text { (Hari) }\end{array}$ & $\begin{array}{c}\text { Jumlah hari } \\
\text { libur dalam } \\
\text { sebulan (Hari) }\end{array}$ & $\begin{array}{c}\text { Available } \\
\text { time } \\
\text { (Jam) }\end{array}$ \\
\hline Apr-2016 & 30 & 4 & 624 \\
\hline May-2016 & 31 & 7 & 576 \\
\hline Jun-2016 & 30 & 4 & 624 \\
\hline Jul-2016 & 31 & 15 & 384 \\
\hline Aug-2016 & 31 & 5 & 624 \\
\hline Sep-2016 & 30 & 5 & 600 \\
\hline Oct-2016 & 31 & 5 & 624 \\
\hline Nov-2016 & 30 & 5 & 600 \\
\hline Dec-2016 & 31 & 6 & 600 \\
\hline Jan-2017 & 31 & 7 & 576 \\
\hline Feb-2017 & 28 & 5 & 552 \\
\hline Mar-2017 & 31 & 6 & 600 \\
\hline TOTAL & 365 & 74 & 6.984 \\
\hline
\end{tabular}

Tabel 4. Perhitungan delay mesin

\begin{tabular}{|c|c|c|c|c|c|c|c|c|}
\hline \multirow[b]{2}{*}{ Buhn } & \multicolumn{7}{|c|}{ Delay Time } & \multirow[b]{2}{*}{$\begin{array}{c}\text { Total } \\
\text { Ddey Tume } \\
\text { (Jam) }\end{array}$} \\
\hline & $\begin{array}{c}\text { Planed } \\
\text { Slop Time } \\
\text { (kam) }\end{array}$ & $\begin{array}{l}\text { Organization } \\
\text { Mayforcion } \\
\text { (lam) }\end{array}$ & $\begin{array}{c}\text { Trouble } \\
\text { Process } \\
\text { (Jamy) }\end{array}$ & $\begin{array}{c}\text { Trabb } \\
\text { Dis } \\
\text { (lam) }\end{array}$ & $\begin{array}{c}\text { Trouble } \\
\text { Machine \& } \\
\text { Bquìmen! } \\
\text { (Jam) }\end{array}$ & $\begin{array}{c}\text { Changeover } \\
\text { Tine } \\
\text { (Jami) }\end{array}$ & $\begin{array}{c}\text { Preparation } \\
\text { Afler Slop } \\
\text { (Jam) }\end{array}$ & \\
\hline Apr-2016 & 38 & 99 & 9 & 2 & 3 & 10 & 8 & 169 \\
\hline May-2016 & 14 & 126 & 12 & 2 & 8 & 14 & 10 & 186 \\
\hline $\operatorname{lan} 2016$ & $\tau$ & 112 & 9 & 0,5 & 0,5 & 10 & 8 & 147 \\
\hline tuk2016 & 181 & 84 & 4 & 3 & 3 & 4 & 4 & 283 \\
\hline $\mathrm{Aug}_{\mathrm{\sigma}} 2016$ & 44 & 105 & 3 & 1 & 1 & 3 & 3 & 160 \\
\hline Sep-2016 & 124 & 108 & $\tau$ & 0 & 0 & $\tau$ & $\tau$ & 253 \\
\hline $0 \mathrm{ct}-2016$ & 12) & 98 & 10 & 9 & 0,5 & 12 & 8 & 257,5 \\
\hline Now2016 & 132 & 102 & 3 & 2 & 3 & 3 & 3 & 248 \\
\hline Dec-2016 & 107 & 95 & 5 & 1 & 0,5 & 5 & 5 & 218,5 \\
\hline $\operatorname{lan} 2017$ & 130 & 111 & 4 & 3 & 1 & 4 & 4 & 257 \\
\hline Fob-2017 & 4 & 100 & 6 & 1 & 3 & 6 & 6 & 126 \\
\hline $\operatorname{Mar} 2017$ & 363 & 90 & $T$ & 3 & 4 & 7 & 7 & 481 \\
\hline
\end{tabular}


pengamatan pada mesin Injection Mold Toshiba Yushine 350 Ton-D di divisi molding. Data delay mesin ditampilkan pada Tabel 4.

\section{Perhitungan Overall Equipment Effectiveness (OEE)}

Hasil perhitungan Overall Equipment Effectiveness terdapat pada Tabel 5.

Tabel 5. Perhitungan overall equipment effectiveness

\begin{tabular}{|c|c|c|c|c|}
\hline Bulan & $\begin{array}{c}\text { Availability } \\
\text { Ratio } \\
(\%)\end{array}$ & $\begin{array}{c}\text { Performance } \\
\text { Efficiency } \\
(\%)\end{array}$ & $\begin{array}{c}\text { Rate Of } \\
\text { Quality } \\
\text { Product } \\
(\%)\end{array}$ & $\begin{array}{c}\text { OEE } \\
(\%)\end{array}$ \\
\hline Apr-2016 & $79 \%$ & $91 \%$ & $98 \%$ & $70 \%$ \\
\hline May-2016 & $71 \%$ & $94 \%$ & $98 \%$ & $65 \%$ \\
\hline Jun-2016 & $79 \%$ & $95 \%$ & $98 \%$ & $73 \%$ \\
\hline Jul-2016 & $52 \%$ & $49 \%$ & $97 \%$ & $25 \%$ \\
\hline Aug-2016 & $81 \%$ & $90 \%$ & $98 \%$ & $71 \%$ \\
\hline Sep-2016 & $74 \%$ & $77 \%$ & $98 \%$ & $56 \%$ \\
\hline Oct-2016 & $74 \%$ & $72 \%$ & $89 \%$ & $48 \%$ \\
\hline Nov-2016 & $76 \%$ & $62 \%$ & $74 \%$ & $35 \%$ \\
\hline Dec-2016 & $78 \%$ & $79 \%$ & $97 \%$ & $60 \%$ \\
\hline Jan-2017 & $72 \%$ & $74 \%$ & $98 \%$ & $53 \%$ \\
\hline Feb-2017 & $79 \%$ & $96 \%$ & $98 \%$ & $74 \%$ \\
\hline Mar-2017 & $53 \%$ & $37 \%$ & $97 \%$ & $19 \%$ \\
\hline
\end{tabular}

Dari hasil perhitungan nilai OEE tiap bulannya, didapatkan beberapa nilai yang memiliki pencapaian nilai OEE dibawah rata-rata. Komposisi ketiga rasio utama OEE tersebut didapat pada Gambar 2. Dari Gambar 2 tersebut dapat dilihat bahwa rendahnya nilai OEE yang utama disebabkan rendahnya pencapaian nilai availability ratio kemudian performance efficiency. Dengan demikian dapat disimpulkan permasalahan utama yang menyebabkan rendahnya pencapaian nilai OEE adalah karena rendahnya nilai availability ratio dan nilai performance efficiency.

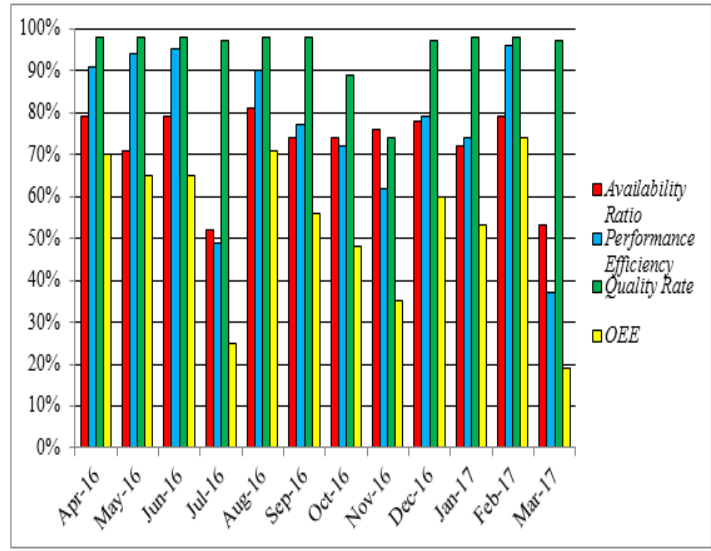

Gambar 2. Pencapaian rasio utama dan OEE di bawah rata-rata

Hasil perhitungan pada Gambar 2 didapatkan nilai OEE (Overall Equipment Effectiveness) dengan nilai tertinggi yaitu pada bulan Februari 2017 sebesar 74\%, nilai terendah pada bulan Maret 2017 sebesar 19\% dan dengan rata-rata nilai persentase sebesar $54 \%$. Maka dengan nilai tertinggi OEE sebesar 74\% masih dapat diterima sebagai nilai efektif suatu mesin itu baik oleh beberapa literature tetapi belum efektif nilai suatu mesin untuk ukuran standar JIPM (Japan Institude of Plant Maintenance) harus melebihi nilai sebesar 85\%. Sehingga dapat dikatakan pada nilai OEE sebesar $74 \%$ ini masih belum efektif. Oleh karena itu diperlukan analisis lebih lanjut untuk mengetahui apa saja penyebab rendahnya nilai OEE dengan perhitungan Six Big Losses dan alternatif solusi yang dapat dilakukan dengan metode diagram pareto serta diagram fishbone.

\section{Perhitungan Six Big Losses}

Tabel 6. Perhitungan persentase Equipment Failure Loss

\begin{tabular}{|c|c|c|c|}
\hline Bulan & $\begin{array}{c}\text { Total } \\
\text { Breakdown } \\
\text { Time } \\
\text { (Jam) }\end{array}$ & $\begin{array}{c}\text { Loading } \\
\text { Time (Jam) }\end{array}$ & $\begin{array}{c}\text { \% Equipment } \\
\text { Failure Loss } \\
\text { (Jam) }\end{array}$ \\
\hline Apr-2016 & 5 & 586 & $1 \%$ \\
\hline May-2016 & 10 & 562 & $2 \%$ \\
\hline Jun-2016 & 0,5 & 617 & $0,08 \%$ \\
\hline Jul-2016 & 3 & 203 & $1 \%$ \\
\hline Aug-2016 & 0,3 & 580 & $0,05 \%$ \\
\hline Sep-2016 & 0 & 476 & $0 \%$ \\
\hline Oct-2016 & 9,5 & 504 & $1,8 \%$ \\
\hline Nov-2016 & 5,5 & 468 & $1,1 \%$ \\
\hline Dec-2016 & 0,8 & 493 & $0,1 \%$ \\
\hline Jan-2017 & 4,6 & 446 & $1,03 \%$ \\
\hline Feb-2017 & 4 & 548 & $1 \%$ \\
\hline Mar-2017 & 6,8 & 237 & $2,8 \%$ \\
\hline \multicolumn{3}{|c|}{ TOTAL } & $5 \%$ \\
\hline
\end{tabular}

\section{Setup and Adjustment}

Tabel 7. Perhitungan persentase setup and adjustment

\begin{tabular}{|c|c|c|c|c|c|}
\hline \multirow[b]{2}{*}{ Bulan } & \multicolumn{2}{|c|}{ Setup and Adjustment } & \multirow[b]{2}{*}{$\begin{array}{l}\text { Total } \\
\text { (Jam) }\end{array}$} & \multirow[b]{2}{*}{$\begin{array}{l}\text { Loading } \\
\text { Time } \\
\text { (Jam) }\end{array}$} & \multirow[b]{2}{*}{$\begin{array}{c}\text { Setup } \\
\text { Loss } \\
(\%)\end{array}$} \\
\hline & $\begin{array}{c}\text { Changeover } \\
\text { Time } \\
\text { (Jam) }\end{array}$ & $\begin{array}{c}\text { Trouble } \\
\text { Process } \\
\text { (Jam) }\end{array}$ & & & \\
\hline Apr-2016 & 10 & 9 & 19 & 586 & $3 \%$ \\
\hline May-2016 & 14 & 12 & 26 & 562 & $5 \%$ \\
\hline Jun-2016 & 10 & 9 & 19 & 617 & $3 \%$ \\
\hline Jul-2016 & 4 & 4 & 8 & 203 & $4 \%$ \\
\hline Aug-2016 & 3 & 3 & 6 & 580 & $1 \%$ \\
\hline Sep-2016 & 7 & 7 & 14 & 476 & $3 \%$ \\
\hline Oct-2016 & 12 & 10 & 22 & 504 & $4 \%$ \\
\hline Nov-2016 & 3 & 3 & 6 & 468 & $1 \%$ \\
\hline Dec-2016 & 5 & 5 & 10 & 493 & $2 \%$ \\
\hline Jan-2017 & 4 & 4 & 8 & 446 & $2 \%$ \\
\hline Feb-2017 & 6 & 6 & 12 & 548 & $2 \%$ \\
\hline Mar-2017 & 7 & 7 & 14 & 237 & $6 \%$ \\
\hline \multicolumn{3}{|c|}{ TOTAL } & 164 & & \\
\hline
\end{tabular}

\section{Speed Losses}

Faktor-faktor yang dikategorikan dalam speed losses adalah idling and minor stoppages dan reduced speed losses.

\section{Idling and minor stoppages}


Tabel 8. Perhitungan persentase Idling and Minor Stoppages

\begin{tabular}{|c|c|c|c|c|c|}
\hline Bulan & $\begin{array}{c}\text { Preparation } \\
\text { After Stop } \\
\text { (Jam) }\end{array}$ & $\begin{array}{c}\text { Organization } \\
\text { Malfuncion } \\
\text { (Jam) }\end{array}$ & $\begin{array}{c}\text { TOTAL } \\
\text { Not } \\
\text { Productive } \\
\text { Time } \\
\text { (Jam) }\end{array}$ & $\begin{array}{c}\text { Loading } \\
\text { Time } \\
\text { (Jam) }\end{array}$ & $\begin{array}{c}\text { Idling and } \\
\text { Minor } \\
\text { Stoppages } \\
(\%)\end{array}$ \\
\hline Apr-2016 & 8 & 99 & 107 & 586 & $18 \%$ \\
\hline May-2016 & 10 & 126 & 136 & 562 & $24 \%$ \\
\hline Jun-2016 & 8 & 112 & 120 & 617 & $19 \%$ \\
\hline Jul-2016 & 4 & 84 & 88 & 203 & $43 \%$ \\
\hline Aug-2016 & 3 & 105 & 108 & 580 & $19 \%$ \\
\hline Sep-2016 & 7 & 108 & 115 & 476 & $24 \%$ \\
\hline Oct-2016 & 8 & 98 & 106 & 504 & $21 \%$ \\
\hline Nov-2016 & 3 & 102 & 105 & 468 & $22 \%$ \\
\hline Dec-2016 & 5 & 95 & 100 & 493 & $20 \%$ \\
\hline Jan-2017 & 4 & 111 & 115 & 446 & $26 \%$ \\
\hline Feb-2017 & 6 & 100 & 106 & 548 & $19 \%$ \\
\hline Mar-2017 & 7 & 90 & 97 & 237 & $41 \%$ \\
\hline \multicolumn{7}{|c|}{ TOTAL } & 1.303 & & \\
\hline
\end{tabular}

\section{Reduced Speed Losses}

Tabel 9. Perhitungan Reduced Speed Losses

\begin{tabular}{c|c|c|c|c|c|c}
\hline Bulan & $\begin{array}{c}\text { Operation } \\
\text { Time } \\
\text { (Jam) }\end{array}$ & $\begin{array}{c}\text { Ideal } \\
\text { Cycle } \\
\text { Time } \\
\text { (Jam) }\end{array}$ & $\begin{array}{c}\text { Total } \\
\text { Productive } \\
\text { Process } \\
\text { (PartOK) }\end{array}$ & $\begin{array}{c}\text { Loading } \\
\text { Time (Jam) }\end{array}$ & $\begin{array}{c}\text { Reduce Speed } \\
\text { Loss Time } \\
\text { (Jam) }\end{array}$ & $\begin{array}{c}\text { Reduce } \\
\text { Speed } \\
\text { Loss \% }\end{array}$ \\
\hline Apr-2016 & 463 & 0,007461 & 56.218 & 586 & 43,53 & $7 \%$ \\
\hline May-2016 & 400 & 0,006218 & 60.209 & 562 & 25,62 & $5 \%$ \\
\hline Jun-2016 & 485 & 0,007634 & 60.199 & 617 & 25,45 & $4 \%$ \\
\hline Jul-2016 & 105 & 0,001581 & 32.517 & 203 & 53,60 & $26 \%$ \\
\hline Aug-2016 & 467 & 0,023315 & 18.021 & 580 & 46,85 & $8 \%$ \\
\hline Sep-2016 & 354 & 0,006839 & 39.669 & 476 & 82,69 & $17 \%$ \\
\hline Oct-2016 & 374,5 & 0,013172 & 20.407 & 504 & 105,69 & $21 \%$ \\
\hline Nov-2016 & 355 & 0,008090 & 27.057 & 468 & 136,1 & $29 \%$ \\
\hline Dec-2016 & 386,5 & 0,007621 & 40.295 & 493 & 79,41 & $16 \%$ \\
\hline Jan-2017 & 323 & 0,102507 & 2.347 & 446 & 82,42 & $18 \%$ \\
\hline Feb-2017 & 432 & 0,007429 & 55.695 & 548 & 18,25 & $3 \%$ \\
\hline Mar-2017 & 126 & 0,000793 & 58.092 & 237 & 79,94 & $34 \%$ \\
\hline \multicolumn{7}{|c|}{ T0TAL } \\
\cline { 1 - 2 }
\end{tabular}

\section{Defect Losses}

Faktor yang dikategorikan kedalam defect losses adalah rework loss dan yield/scrap loss:

\section{Rework Loss}

Tabel 10. Perhitungan persentase Rework Losses

\begin{tabular}{|c|c|c|c|c|c|}
\hline Bulan & $\begin{array}{l}\text { Ideal } \\
\text { Cycle } \\
\text { Time } \\
\text { (Jam) }\end{array}$ & $\begin{array}{c}\text { Rework } \\
\text { (pcs) }\end{array}$ & $\begin{array}{c}\text { Loading } \\
\text { Time } \\
\text { (Jam) }\end{array}$ & $\begin{array}{l}\text { Rework } \\
\text { Time } \\
\text { (Jam) }\end{array}$ & $\begin{array}{c}\text { Rework } \\
\text { Loss } \\
(\%)\end{array}$ \\
\hline Apr-2016 & 0,007461 & 780 & 586 & 5,82 & $0,99 \%$ \\
\hline May-2016 & 0,006218 & 877 & 562 & 5,45 & $0,97 \%$ \\
\hline Jun-2016 & 0,007634 & 860 & 617 & 6,57 & $1,06 \%$ \\
\hline Jul-2016 & 0,001581 & 611 & 203 & 0,97 & $0,48 \%$ \\
\hline Aug-2016 & 0,023315 & 272 & 580 & 6,34 & $1,09 \%$ \\
\hline Sep-2016 & 0,006839 & 488 & 476 & 3,34 & $0,70 \%$ \\
\hline Oct-2016 & 0,013172 & 1.518 & 504 & 20,00 & $3,97 \%$ \\
\hline Nov-2016 & 0,008090 & 4.952 & 468 & 40,06 & $8,56 \%$ \\
\hline Dec-2016 & 0,007621 & 774 & 493 & 5,90 & $1,20 \%$ \\
\hline Jan-2017 & 0,102507 & 33 & 446 & 3,38 & $0,76 \%$ \\
\hline Feb-2017 & 0,007429 & 884 & 548 & 6,57 & $1,20 \%$ \\
\hline Mar-2017 & 0,000793 & 1.184 & 237 & 0,94 & $0,40 \%$ \\
\hline \multicolumn{4}{|c|}{ TOTAL } & 105,33 & \\
\hline
\end{tabular}

\section{Yield/Scrap Losses}

Tabel 11. Perhitungan Yield/Scrap loss

\begin{tabular}{|c|c|c|c|c|c|}
\hline Bulan & $\begin{array}{c}\text { Ideal Cycle } \\
\text { Time } \\
\text { (Jam) }\end{array}$ & Scrap & $\begin{array}{c}\text { Loading } \\
\text { Time } \\
\text { (Jam) }\end{array}$ & $\begin{array}{c}\text { Scrap } \\
\text { time } \\
\text { (Jam) }\end{array}$ & $\begin{array}{c}\text { Scrap } \\
\text { loss } \\
(\%)\end{array}$ \\
\hline Apr-2016 & 0,007461 & 334 & 586 & 2,49 & $0,43 \%$ \\
\hline May-2016 & 0,006218 & 375 & 562 & 2,33 & $0,41 \%$ \\
\hline Jun-2016 & 0,007634 & 368 & 617 & 2,81 & $0,46 \%$ \\
\hline Jul-2016 & 0,001581 & 261 & 203 & 0,41 & $0,20 \%$ \\
\hline Aug-2016 & 0,023315 & 116 & 580 & 2,70 & $0,47 \%$ \\
\hline Sep-2016 & 0,006839 & 209 & 476 & 1,43 & $0,30 \%$ \\
\hline Oct-2016 & 0,013172 & 650 & 504 & 8,56 & $1,70 \%$ \\
\hline Nov-2016 & 0,008090 & 2.121 & 468 & 17,16 & $3,67 \%$ \\
\hline Dec-2016 & 0,007621 & 331 & 493 & 2,52 & $0,51 \%$ \\
\hline Jan-2017 & 0,102507 & 13 & 446 & 1,33 & $0,30 \%$ \\
\hline Feb-2017 & 0,007429 & 221 & 548 & 1,64 & $0,30 \%$ \\
\hline Mar-2017 & 0,000793 & 507 & 237 & 0,40 & $0,17 \%$ \\
\hline \multicolumn{7}{|c|}{ TOTAL } & & 43,80 & \\
\hline
\end{tabular}

\section{Perhitungan Overall Human Ineffectiveness (OHI)}

Untuk melihat persentase tingkat ketidakefektifan operator pada saat melakukan pekerjaannya adalah dengan rumus (2).

$$
\begin{gathered}
\mathrm{OHI}=\% \text { Inefectivenes Effort } \mathrm{x} \% \text { Non Value } \\
\text { Added Effort }
\end{gathered}
$$

Tabel 12. Perhitungan Overall Human Ineffectiveness

\begin{tabular}{|c|c|c|c|}
\hline Bulan & $\begin{array}{c}\text { \% Ineffective } \\
\text { Effort }\end{array}$ & $\begin{array}{c}\text { \% Non Value } \\
\text { Added Effort }\end{array}$ & OHI \\
\hline Apr-2016 & $21 \%$ & $70 \%$ & $14 \%$ \\
\hline May-2016 & $28 \%$ & $60 \%$ & $17 \%$ \\
\hline Jun-2016 & $21 \%$ & $74 \%$ & $16 \%$ \\
\hline Jul-2016 & $25 \%$ & $20 \%$ & $5 \%$ \\
\hline Aug-2016 & $17 \%$ & $68 \%$ & $12 \%$ \\
\hline Sep-2016 & $20 \%$ & $53 \%$ & $10 \%$ \\
\hline Oct-2016 & $22 \%$ & $56 \%$ & $13 \%$ \\
\hline Nov-2016 & $19 \%$ & $53 \%$ & $10 \%$ \\
\hline Dec-2016 & $18 \%$ & $60 \%$ & $11 \%$ \\
\hline Jan-2017 & $20 \%$ & $48 \%$ & $10 \%$ \\
\hline Feb-2017 & $21 \%$ & $71 \%$ & $15 \%$ \\
\hline Mar-2017 & $18 \%$ & $16 \%$ & $3 \%$ \\
\hline
\end{tabular}

\section{Faktor - Faktor Penyebab Kerusakan Mesin}

Setelah mengetahui nilai Overall Equipment Effectiveness (OEE), Six Big Losses dan Overall Human Ineffectiveness (OHI), maka selanjutnya menganalisis faktor penyebab terjadinya kerusakan mesin dengan menggunakan metode analisis Six Big Losses, serta menggunakan diagram histogram, pareto dan fishbone.

\section{Analisis Six Big Losses}

Untuk melihat lebih jelas six big losses yang mempengaruhi efektivitas mesin, maka akan dilakukan perhitungan time loss untuk masing-masing faktor dalam six big loss tersebut seperti yang dilihat pada hasil perhitungan di Tabel 13. 
Tabel 13. Persentase faktor Six Big Losses.

\begin{tabular}{|c|c|c|c|}
\hline No. & Six Big Losses & $\begin{array}{c}\text { Total Time } \\
\text { Losses (Jam) }\end{array}$ & $\begin{array}{c}\text { Persentase } \\
(\%)\end{array}$ \\
\hline 1 & Breakdown Losses & 22 & $1 \%$ \\
\hline 2 & Setup and Adjustment Loss & 164 & $7 \%$ \\
\hline 3 & Reduced Speed Loss & 779,55 & $32 \%$ \\
\hline 4 & Idling and Minor Stoppages Loss & 1.303 & $54 \%$ \\
\hline 5 & Rework Loss & 105,33 & $4 \%$ \\
\hline 6 & Scrap/yield Loss & 43,80 & $2 \%$ \\
\hline \multicolumn{2}{|c|}{ TOTAL } & 2.418 & $100 \%$ \\
\hline
\end{tabular}

Persentase time loss dari keenam faktor tersebut juga akan lebih jelas lagi diperlihatkan dalam bentuk histogram yang terlihat pada Gambar 3.

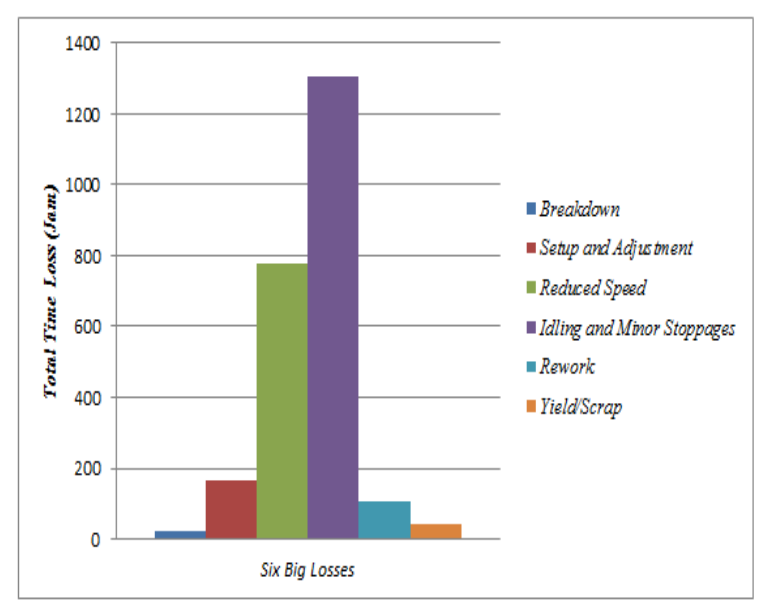

Gambar 3. Histogram persentase faktor Six Big Losses.

Dari histogram dapat dilihat bahwa faktor yang memiliki persentase terbesar dari keenam faktor tersebut adalah Idling and Minor Stoppages sebesar 1.303 Jam. Untuk melihat urutan persentase keenam faktor tersebut mulai yang terbesar dapat dilihat pada Tabel 14.

Tabel 14. Pengurutan persentase faktor Six Big Losses.

\begin{tabular}{|c|c|c|c|c|}
\hline No. & Six Big Losses & $\begin{array}{c}\text { Total Time } \\
\text { Losses } \\
\text { (Jam) }\end{array}$ & $\begin{array}{c}\text { Persentase } \\
(\%)\end{array}$ & $\begin{array}{l}\text { Persentase } \\
\text { Komulatif }\end{array}$ \\
\hline 1 & Idling and Minor Stoppages Loss & 1.303 & $54 \%$ & $54 \%$ \\
\hline 2 & Reduced Speed Loss & 779,55 & $32 \%$ & $86 \%$ \\
\hline 3 & Setup and Adjustment Loss & 164 & $7 \%$ & $93 \%$ \\
\hline 4 & Rework Loss & 105,33 & $4 \%$ & $97 \%$ \\
\hline 5 & Scrapiyield Loss & 43,80 & $2 \%$ & $99 \%$ \\
\hline 6 & Breakdown Losses & 22 & $1 \%$ & $100 \%$ \\
\hline & TOTAL & 2.418 & $100 \%$ & \\
\hline
\end{tabular}

Dari hasil pengurutan persentase faktor six big losses tersebut akan digambarkan diagram pareto sehingga terlihat jelas urutan dari keenam faktor yang mempengaruhi efektivitas mesin Injection Mold 350 Ton-D. Dengan analisis diagram pareto terhadap seluruh jenis losses, akar permasalahan yang sesungguhnya dapat ditemui. Dari six big losses dapat digambarkan diagram pareto (Gambar 4), yang memperlihatkan dengan jelas pengaruh six big losses tersebut terhadap efektifitas mesin Injection Mold. Pada Gambar 4 diagram pareto terlihat bahwa idling and minor stoppages losses merupa- kan faktor dominan yang menyebabkan rendahnya nilai Overall Equipment Effectiveness (OEE).

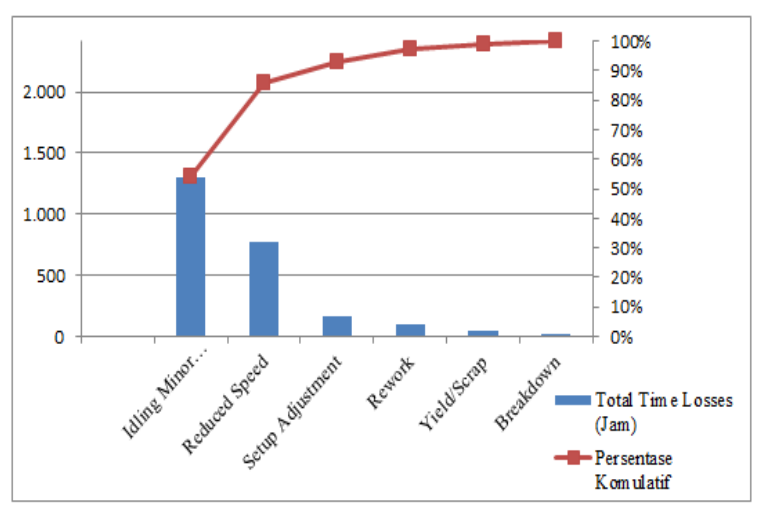

Gambar 4. Diagram Pareto

Diagram pareto juga dikenal sebagai aturan $80 / 20$ dengan melakukan $20 \%$ dari pekerjaan bisa menghasilkan 80\% manfaat dari pekerjaan itu. Aturan 80/20 dapat diterapkan pada hampir semua hal, seperti : $80 \%$ dari keluhan pelanggan timbul karena 20\% dari produk atau jasa, $80 \%$ dari keterlambatan jadwal timbul karena 20\% dari kemungkinan penyebab penundaan. Pada diagram diatas terlihat $80 \%$ faktor gangguan Idling and $\mathrm{Mi}$ nor Stoppagges berasal dari 20\% masalah yang ada diagram sebelahnya yaitu diantara lain Reduced Speed, Setup and Adjustment, Rework, Yield/Scrap dan Breakdown. Maka dari diagram pareto dapat terlihat untuk kedepannya perusahaan harus lebih fokus kepada faktor masalah Idling and Minor Stoppagges tersebut daripada keseluruhan masalah yang ada.

\section{Diagram Sebab Akibat ( Fishbone Diagram)}

Analisis terhadap penyebab faktor-faktor six big losses yang mengakibatkan rendahnya efektivitas mesin dalam perhitungan OEE dilakukan dengan menggunakan diagram sebab akibat (fishbone diagram). Berdasarkan diagram pareto yang telah dibuat, faktor dominannya adalah faktor $I d$ ing and minor stoppagges losses. Gambar 5 menunjukkan diagram sebab akibat (fishbone) untuk faktor idling and minor stoppagges losses disebabkan oleh berhentinya mesin mold dikarenakan terjadi permasalahan sementara. Misalnya pada faktor manusia terjadi kurangnya motivasi pekerjanya dalam bekerja sehingga mengakibatkan kurangnya tingkat kedisiplinan pekerja dalam melakukan pekerjaannya yang secara tidak langsung berdampak pada saat mesin pengalami permasalahan sementara. Faktor Material yaitu terjadi permasalahan material mampet diselang saat melakukan proses produksi yang timbul akibat rendahnya perawatan bahan baku atau material. Faktor mesin yaitu mesin sudah terlalu tua yang mengakibatkan mesin sering terjadi breakdown pada saat proses produksi. Faktor metode yaitu sering dilakukannya perbaikan jika mesin sudah 


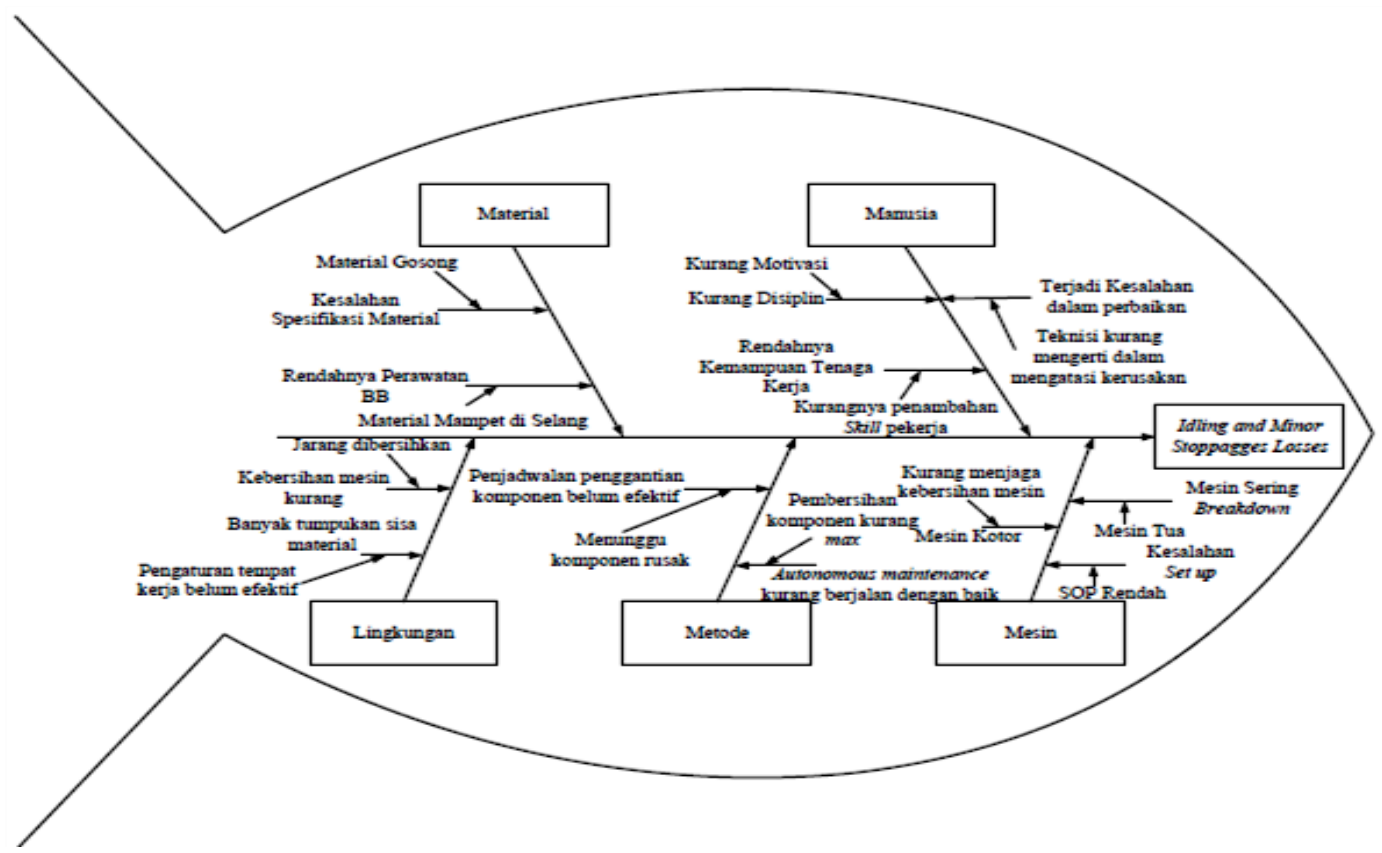

Gambar 5. Diagram sebab akibat (fishbone)

terlanjur rusak, permasalahan ini timbul akibat adanya permasalahan penjadwalan penggantian komponen yang rusak belum efektif. Faktor lingkungan yaitu banyak terjadinya sisa material yang rusak saat proses produksi masih berada dimesin yang tidak dibuang ditempatnya mengakibatkan kebersihan lingkungan sekitar masih kurang efektif.

\section{PENUTUP}

Dari hasil perhitungan tingkat efektif suatu mesin, nilai OEE terbesar berkisar pada 74\% dibulan Februari 2017, yang artinya nilai OEE tersebut belum dapat diterima oleh ukuran standar JIPM (Japan Institute of Plant Maintenance) dikarenakan masih dibawah nilai 85\%.

Dari hasil perhitungan tingkat ketidakefektifan operator nilai OHI terbesar berada pada bulan Mei 2016 daripada bulan-bulan lainnya selama periode satu tahun yaitu dengan nilai OHI 17\%.

Faktor - faktor yang menyebabkan kerusakan mesin adalah Faktor yang memiliki persentase terbesar dari nilai six big losses mesin Injection Mold 350 Ton-D adalah faktor Idling and Minor Stoppagges Losses sebesar 54\%, Reduced Speed Losses sebesar 32\%, Setup and Adjustment Losses sebesar 7\%, Rework Losses 4\%, Scrap/Yield Losses $2 \%$ dan Breakdown Losses sebesar 1\%. Faktor faktor yang menyebabkan terjadinya Idling and Minor Stoppagges Losses yang menjadi prioritas utama adalah :

1. Faktor manusia : kurang disiplin, terjadi kesalahan dalam perbaikan, dan rendahnya kemampuan tenaga kerja.
2. Faktor material : kesalahan spesifikasi material dan rendahnya perawatan bahan baku.

3. Faktor mesin : mesin sering breakdown, kesalahan setup, dan mesin kotor.

4. Faktor metode : penjadwalan pengganti komponen yang belum efektif dan autonomous maintenance kurang berjalan dengan baik.

5. Faktor lingkungan : kebersihan mesin kurang dan banyak sisa tumpukan material.

\section{DAFTAR PUSTAKA}

Ansori, N., \& Mustajib, M. I. (2013). Sistem Perawatan Terpadu. Yogjakarta: Graha Ilmu.

Assauri, S. (1999). Manajemen Produksi dan Operasi. Jakarta: Lembaga Penerbit Fakultas Ekonomi Universitas Indonesia.

Hasriyono, M. (2009). Evaluasi Efektivitas Mesin Dengan Penerapan Total Productive Maintenance (TPM) Di PT Hadi Baru. Universitas Sumatera Utara, Medan.

Herwindo, Rahman, A., \& Yuniarti, R. (2014). PENGUKURAN OVERALL EQUIPMENT EFFECTIVENESS (OEE) SEBAGAI UPAYA MENINGKATKAN NILAI EFEKTIVITAS MESIN CARDING (Studi kasus: PT. XYZ). Jurnal Rekayasa dan Manajemen Sistem Industri , 2 (5), hal. 907-918.

Jono. (2005). Total Productive Maintenance (TPM) pada Perawatan Mesin Boiler Menggunakan Metode Overall Equipment Effectiveness (OEE). Tekinfo - Jurnal Ilmiah Teknik Industri dan Informasi , 3 (2), 46-60.

Kho, B. (2016, Juli 1). Pengertian Total Productive Maintenance (TPM). Dipetik April 6, 2017, dari ILMU MANAJEMEN INDUSTRI: 
http://ilmumanajemenindustri.com/penger tian-total-productive-maintenance-tpm/

Leflar, J. (2001). Practical TPM: successful equipment management at Agilent Technologies. CRC Press.

Nakajima, S. (1988). Introduction to Total Productive Maintenance (TPM). Cambridge: Productivity Press Inc.

PT. Astra Otoparts Divisi IGP Groups. (2002). Diktat Productivity and Quality Management Consultants. Jakarta: TPM2-R5.
Sondalini, M. (2008, August 10). “Oee: Overall Equipment Effectiveness. Article, Business Industrial Network .

Triesnata, A. (2008). Analisa Perawatan Total Productive Maintenance (TPM) Departement Pressing di PT Indomobil Suzuki Internasional. Tugas Akhir.

Williamson, R. M. (2006). Using overall equipment effectiveness: the metric and the measures. Strategic Work System, Inc. 
MT Siregar, dkk / Teknika : Engineering and Sains Journal, Vol. 1, No.2, Desember 2017, 131-140

Halaman ini sengaja dikosongkan 